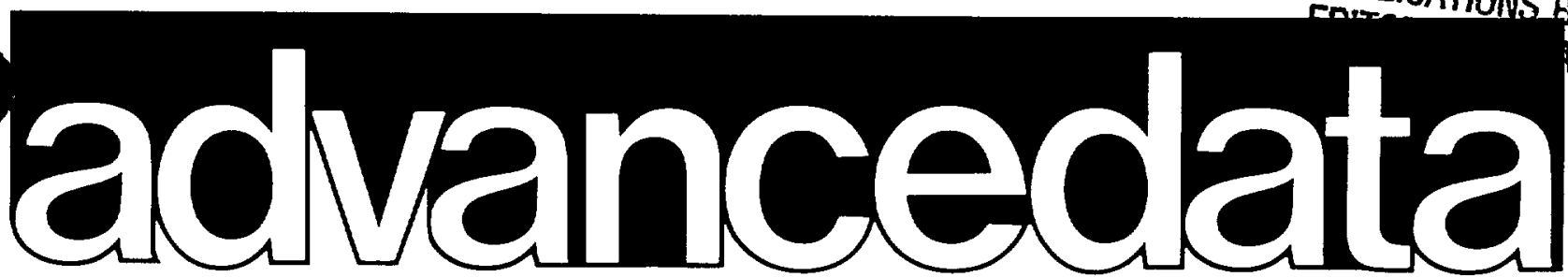
FROM VITAL \& HEALTH STATISTICS OF THE NATIONAL CENTER FOR HEALTH STATISTICS

\title{
Selected Demographic Characteristics of Teenage Wives and Mothers ${ }^{a}$
}

\section{INTRODUCTION}

In the United States in 1976 , about 1,122,000 women 15-19 years of age were married, divorced, widowed, or separated; of these, 480,000 were mothers of at least one child. Another 332,000 women in this age group were never married mothers who had offspring living with them. The 1,122,000 ever married women 15-19 accounted for about 11 percent, and the 332,000 never married mothers, about 3 percent of the 0.4 million women 15-19 years of age in 1976 .

This report provides the first and most recent national estimates of the current contraceptive practice and family background of teenage wives and mothers and their husbands. It also compares them with their counterparts $20-44$ years of age in terms of these and other selected characteristics. These estimates are based on a special analysis of data from Cycle II of the National Survey of Family Growth (NSFG), conducted in 1976 by the National Center for Health Statistics.

A number of trends have prompted recent concern about teenage marriage and childbearing. These trends include the increasing number of women 15-19 years of age (a result of the high birth rate during the late 1950 's), the increasing number of teenage marriages, and the increasing proportion of all births occurring to teenage mothers.

The U.S. Bureau of the Census has reported that the number of women 15-19 years of age increased by 57 percent from 1960 through

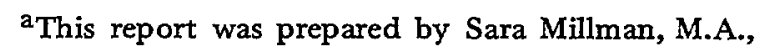
nd William D. Mosher, Ph.D., Division of Vital Staistics.
1976, from 6.6 million to 10.4 million. Reflecting this increase in the number of young women, the annual numbers of teenage marriages also increased over the same period.

However, the rates for teenage marriages and births did not increase. Data from the marriage registration system (table 1) show that of all brides marrying for the first time in 1976 about 38 percent (or 571,000 ) were under 20 years of age. In 1960 teenage brides had accounted for 48 percent (or 482,000) of all first marriages.

From 1940 through 1960 , birth rates to women 15-19 years of age (births per 1,000 women 15-19) increased from 54.1 to 89.1. From 1960 through 1976, however, this rate decreased from 89.1 to 53.5 , a 40 percent reduction, and approximately the 1940 level. Among women 20 years of age and older, however, birth rates declined even more from 1960 through 1976.1 As a result of this differential decline and the increase in the number of women 15-19 years of age, births to teenage mothers accounted for 18 percent of all births in 1976, compared with 14 percent in 1960 . Since 1976, the birth rates for women 15-19 have remained at about the same levels.

The data for this report were collected by means of personal interviews with a multistage area probability sample of women $15-44$ years of age in the household population of the conterminous United States. Women were eligible for inclusion in the sample if they were currently married, previously married, or never married but with offspring presently living in the household. This report does not include the relatively small number of teenage mothers under 15 years of age. ${ }^{2}$ Similarly, never married teenage mothers whose offspring were not living with them were 
Table 1. Number of first marriages and percent distribution by age of bride and age of groom at first marriage: United States, 1960 and 1976

\begin{tabular}{|c|c|c|c|c|}
\hline \multirow{2}{*}{ Age } & \multicolumn{2}{|c|}{ Bride } & \multicolumn{2}{|c|}{ Groom } \\
\hline & 1976 & 1960 & 1976 & 1960 \\
\hline 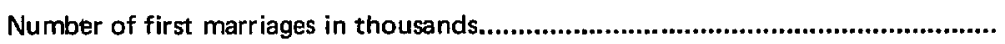 & 1,491 & 1,015 & 1,450 & 1,028 \\
\hline Age at first marriage & \multicolumn{4}{|c|}{ Percent distribution } \\
\hline 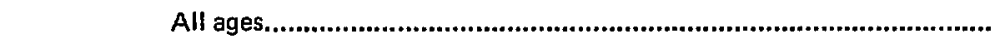 & 100.0 & 100.0 & 100.0 & 100.0 \\
\hline 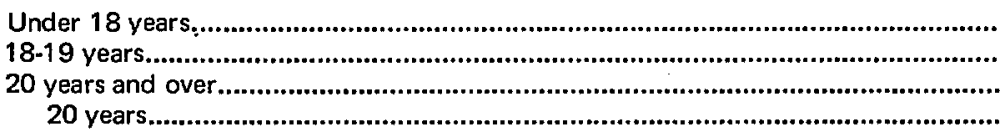 & $\begin{array}{l}11.9 \\
26.4 \\
61.6 \\
12.1\end{array}$ & $\begin{array}{l}15.1 \\
32.4 \\
52.5 \\
11.0\end{array}$ & $\begin{array}{r}2.1 \\
15.4 \\
82.5 \\
10.9\end{array}$ & $\begin{array}{r}1.8 \\
15.2 \\
83.0 \\
9.1\end{array}$ \\
\hline
\end{tabular}

SOURCES: National Center for Health Statistics: Vital Statistics of the United States, 1960, Vol. III, Marriage and Divorce. Public Health Service. Washington. U.S. Government Printing Office, 1964. table 2-6.

National Center for Health Statistics: First marriages, United States, 1968-1976, by B. F. Wilson and E. Hume. Vital and Health Statistics. Series 21-No. 35. DHEW Pub. No. (PHS) 79-1913. Public Health Service. Washington. U.S. Government Printing Office, Sept. 1979, tables $B$ and $C$ and unpublished tabulations.

not included in the sample. (Approximately 7 percent of out-of-wedlock babies born to women aged 15-19 were not living with their mothers in 1976. The comparable figure for 1971 was about 14 percent. It should be noted, however, that these percents are based on only 148 cases in 1976 and 259 cases in 1971 and refer only to out-of-wedlock babies born from first conceptions. They should, therefore, be interpreted with some caution. ${ }^{3}$ )

From January through September 1976, 3,009 black women and 5,602 women of other races were interviewed in the NSFG. Of these, 448 women were $15-19$ years of age. This report is based on information provided by these teenage women, of whom 193 were black and 255 were of races other than black. The information from these women was inflated to provide national estimates of these statistics. Because they are based on a sample, estimates from the NSFG are subject to sampling error. Further discussion of sampling error, comparisons with other data, and definitions of selected terms can be found in the Technical Notes.

The statistics on women 20-44 years of age are shown in this report only for purposes of comparison. Other groups could be used, but this group is convenient for the purposes this report-principally, to highlight some of th characteristics of teenage wives and mothers. It should not necessarily be inferred that teenage marriage or childbearing is the only or the principal cause of differences between teenagers and the older women described. These differences may be the result of such things as their ages at interview or the social customs prevailing when they were married or when they had their children.

\section{CHARACTERISTICS OF EVER MARRIED TEENAGE WOMEN AND THEIR HUSBANDS}

Tables 2 and 3 present selected characteristics of the $1,122,000$ ever married teenage women and their husbands and of the 30,725,000 ever married women 20-44 years of age and their current or last husbands, in the United States in 1976. (In this report, for convenience, the ever married teenage women are referred to as "teenage wives," although a very small proportion of them were no longer currently married at the time of interview. See Definitions Terms.) 
Table 2. Number of ever married women 15-44 years of age, by age and race, and percent distribution by selected characteristics, according to age and race: United States, 1976

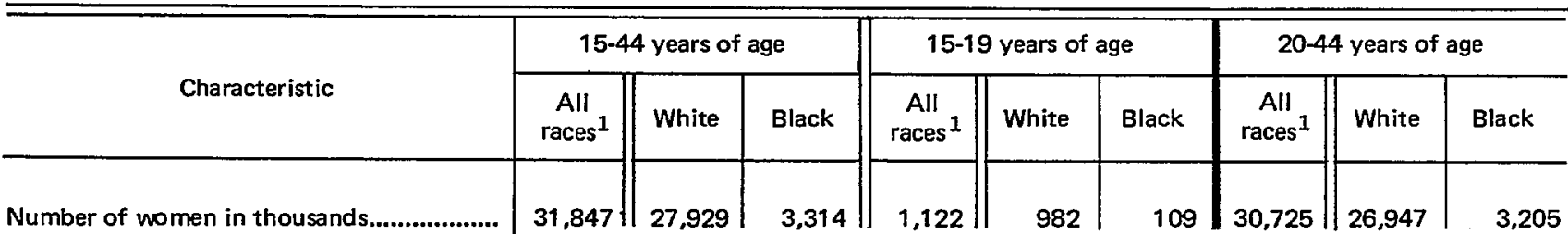

All women.

\section{Age}

15-17 years

18-19 years

20-24 years

25-29 years

$30-44$ years

Age at marriage

Under 18 years

$18-19$ years.

20-44 years.

Age at first birth

Under 18 years

18-19 years.

20-44 years.

No live births.

\section{Timing of first birth}

Premarital birth.

0-7 months after marriage

8 months after marriage or more.

No live births.

\section{Children ever born}

None

2 or more.

\section{Education}

0-11 years

12 years or more

\section{Poverty level income}

Below poverty level income

Poverty level income and above.

\section{Labor force status}

In the labor force

Working

Unemployed or with a job but not at

nork

Not in the labor force

In school.

Keeping house or other

See footnote at end of table.
Percent distribution

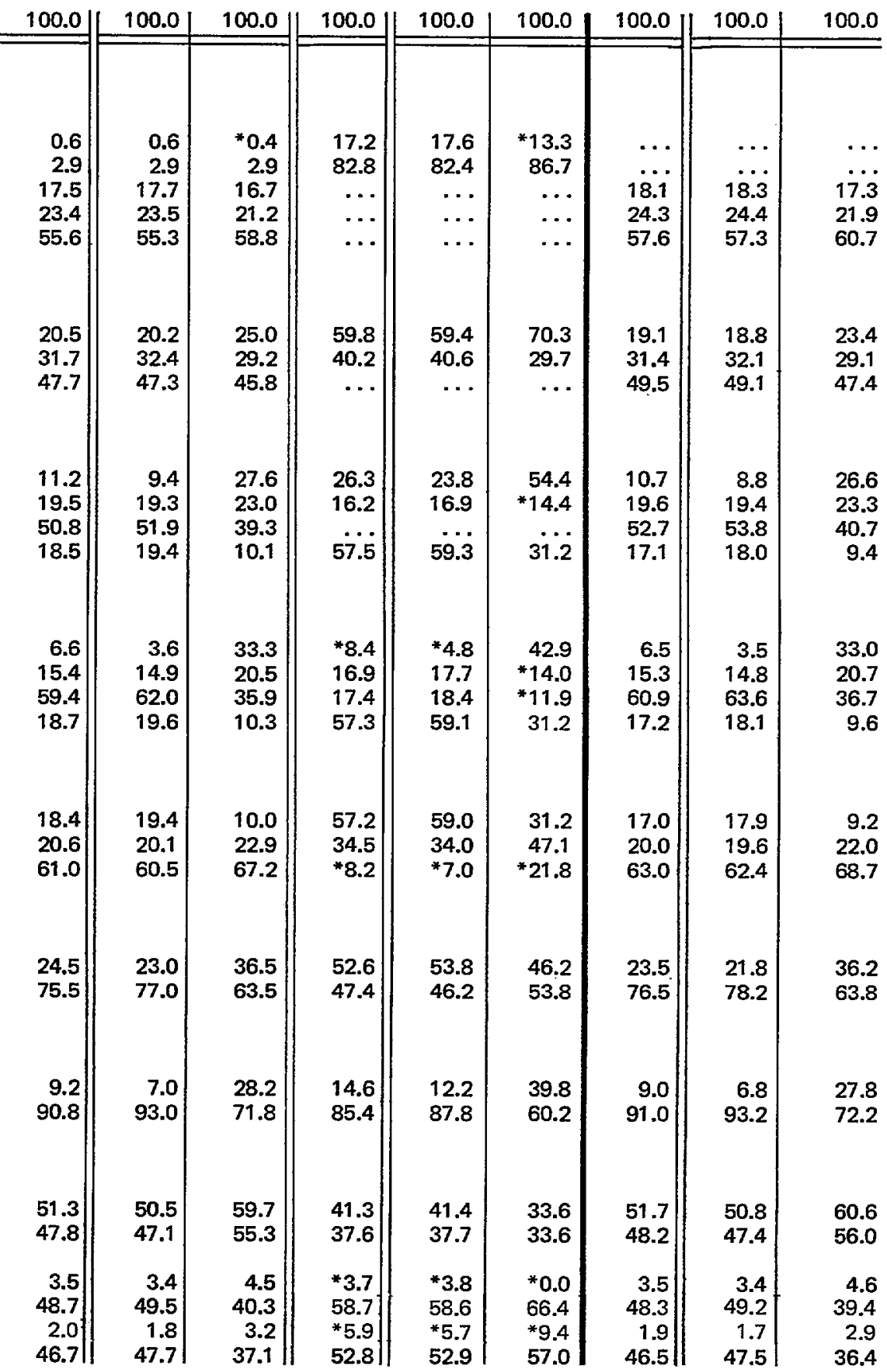


Table 2. Number of ever married women 15-44 years of age, by age and race, and percent distribution by selected characteristics, according to age and race: United States, 1976-Con.

\begin{tabular}{|c|c|c|c|c|c|c|c|c|c|}
\hline \multirow[b]{2}{*}{ Characteristic } & \multicolumn{3}{|c|}{$15-44$ years of age } & \multicolumn{3}{|c|}{$15-19$ years of age } & \multicolumn{3}{|c|}{$20-44$ years of age } \\
\hline & $\begin{array}{c}\text { All } \\
\text { races }^{1}\end{array}$ & White & Black & $\begin{array}{l}\text { All } \\
\text { races }^{1}\end{array}$ & White & Black & races $^{1}$ & White & Black \\
\hline With Dependent Children (AFDC) & \multicolumn{9}{|c|}{ Percent distribution } \\
\hline 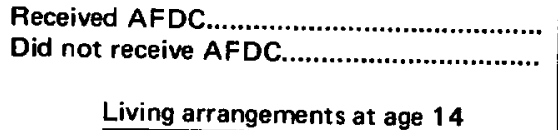 & $\begin{array}{r}7.1 \\
92.9\end{array}$ & $\begin{array}{r}5.4 \\
94.6\end{array}$ & $\begin{array}{l}20.4 \\
79.6\end{array}$ & $\begin{array}{r}9.4 \\
90.6\end{array}$ & $\begin{array}{l}8.5 \\
91.5\end{array}$ & $\begin{array}{r}* 19.8 \\
80.2\end{array}$ & $\begin{array}{r}7.0 \\
93.0\end{array}$ & $\begin{array}{r}5.3 \\
94.7\end{array}$ & $\begin{array}{l}20.4 \\
79.6\end{array}$ \\
\hline $\begin{array}{l}\text { Living with both parents............................ } \\
\text { Living with one or neither parent................. } \\
\text { Current contraceptive status }\end{array}$ & $\begin{array}{l}76.7 \\
23.3\end{array}$ & $\begin{array}{l}79.1 \\
20.9\end{array}$ & $\begin{array}{l}56.5 \\
43.5\end{array}$ & $\begin{array}{l}56.3 \\
43.7\end{array}$ & $\begin{array}{l}58.3 \\
41.7\end{array}$ & $\begin{array}{l}50.1 . \\
49.9\end{array}$ & $\begin{array}{l}77.4 \\
22.6\end{array}$ & $\begin{array}{l}79.8 \\
20.2\end{array}$ & $\begin{array}{l}56.7 \\
43.3\end{array}$ \\
\hline 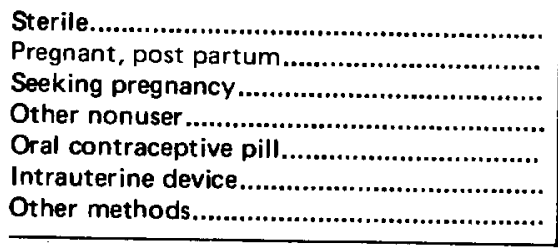 & $\begin{array}{r}29.6 \\
6.1 \\
5.6 \\
10.7 \\
22.7 \\
6.6 \\
18.6\end{array}$ & $\begin{array}{r}30.2 \\
6.2 \\
5.3 \\
9.7 \\
23.0 \\
6.5 \\
19.1\end{array}$ & \begin{tabular}{r|}
26.5 \\
5.5 \\
6.3 \\
18.5 \\
21.6 \\
7.1 \\
14.5
\end{tabular} & $\begin{array}{l}* 1.8 \\
14.5 \\
* 7.7 \\
6.9 \\
50.7 \\
6.5 \\
12.0\end{array}$ & $\begin{array}{l}* 1.7 \\
15.0 \\
* 5.9 \\
* 6.5 \\
51.6 \\
* 6.3 \\
13.0\end{array}$ & $\begin{array}{r}* 3.2 \\
* 14.1 \\
* 11.3 \\
* 12.0 \\
48.2 \\
* 9.1 \\
* 2.1\end{array}$ & $\begin{array}{r}30.7 \\
5.8 \\
5.5 \\
10.8 \\
21.7 \\
6.6 \\
18.9\end{array}$ & $\begin{array}{r}31.3 \\
5.9 \\
5.3 \\
9.8 \\
22.0 \\
6.5 \\
19.3\end{array}$ & $\begin{array}{r}27.3 \\
5.2 \\
6.1 \\
18.8 \\
20.7 \\
7.1 \\
14.9\end{array}$ \\
\hline
\end{tabular}

NOTE: Statistics in tables 2,3, and 4 are based on a sample of the household population of the conterminous United States. See Technical Notes for estimates of sampling variability and definitions of selected terms.

About 5 of 6 ( 83 percent) of the teenage wives were $18-19$ years of age. Only 17 percent were 15-17 years of age. Table 2 shows that about 31 percent of ever married women 20-44 years of age had their first child before the age of 20. The differences described in this report between ever married teenagers and ever married women 20-44 would probably be larger if women who had first married or had had their first child as teenagers were excluded from the age group 20-44. For an analysis of differences in fertility after the teen years between women who had a teenage birth and women who did not, and a review of the literature on some other differences between teenage mothers and other women, see reference 4 .

Living arrangements of the respondent at age 14 may be viewed as an indicator of the stability of her family life while she was growing up. By this indicator the family background of teenage wives was more likely to have been unstable than that of other wives. About 44 percent of teenage ever married women, com- pared with only 23 percent of ever married women 20-44 years of age, were living with only one or neither parent at age 14. A report by the U.S. Bureau of the Census indicates that about 21 percent of persons 10-17 years of age were living with only one or neither parent in $1976 . .^{5}$

Although only 17 percent of teenage wives were under 18 years of age, about 53 percent had not completed high school by the date of the interview. This suggests that the education of some of the teenage wives was interrupted or terminated by marriage or childbearing. ${ }^{6}$ Teenage wives were significantly less likely to have completed high school than wives aged 20-44: 47 percent of teenage wives and 77 percent of wives 20-44 had completed 12 years of education by the date of interview.

Teenage wives were significantly more likely than wives aged 20-44 to have had no births (57 percent compared with 17 percent) or only one birth (34 percent compared with 20 percent) by the date of interview. Teenage wives were also significantly more likely to be preg- 
Table 3. Number of ever married women $\mathbf{1 5 - 4 4}$ years of age, by age and race, and percent distribution by selected characteristics of their current or last husband, according to age and race: United States, 1976

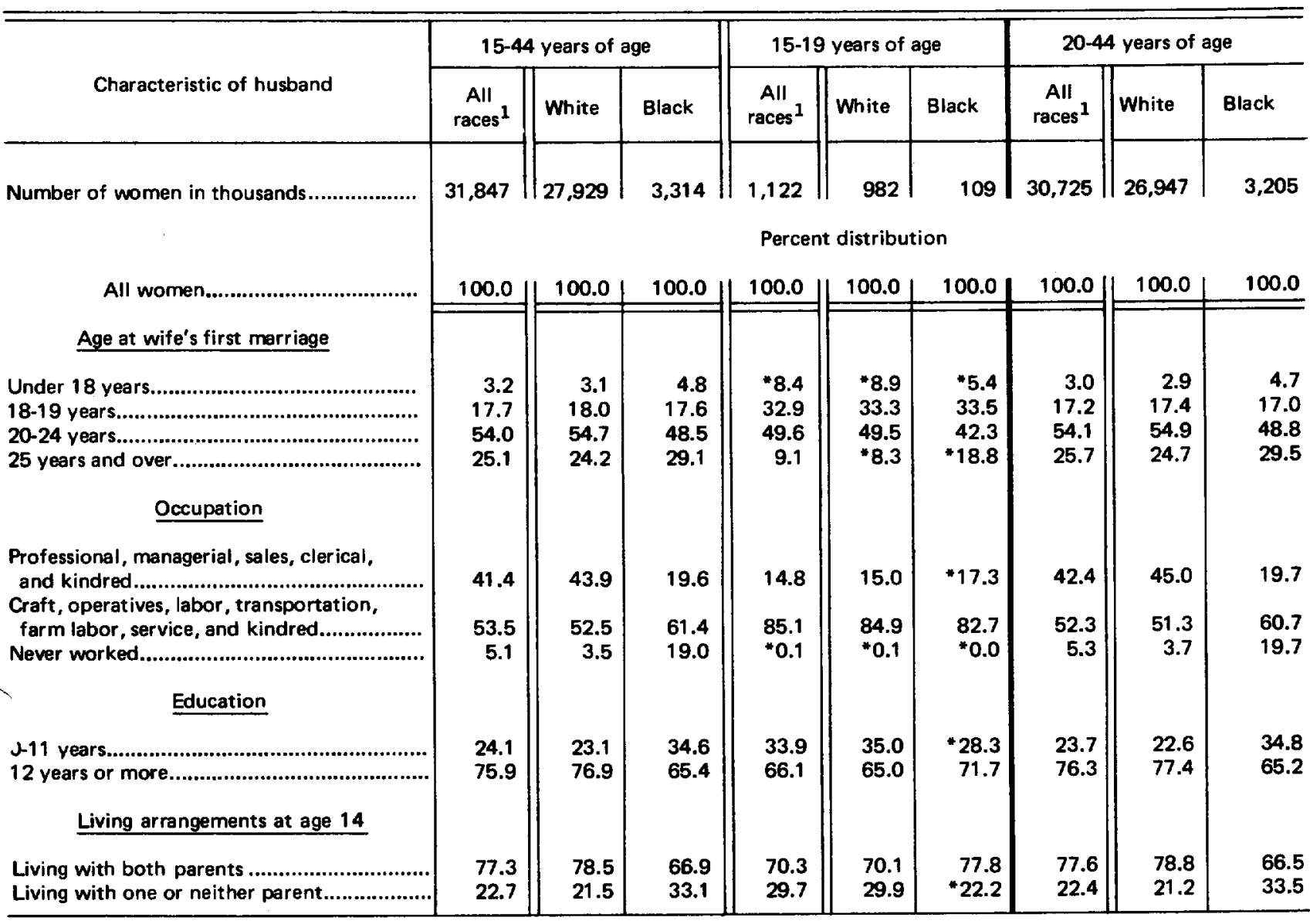

${ }^{1}$ Includes white, black, and other races.

NOTE: Statistics in tables 2, 3, and 4 are based on a sample of the household population of the conterminous United States. See Technical Notes for estimates of sampling variability and definitions of selected terms.

nant or post partum at the date of interview than wives 20.44 years of age ( 15 percent compared with 6 percent).

Teenage wives were not significantly more likely than wives $20-44$ years of age to have had a premarital birth (8 percent compared with 7 percent). Similarly, the teenage wives were not significantly more likely to have had a premarital conception: the proportion of wives whose first birth occurred within 7 months of marriage was 17 percent for teenage wives and 15 percent for the women 20-44 years of age, not a significant difference.

About 15 percent of ever married teenage women were living in households with below poverty level incomes, compared with about 9 percent of ever married women 20-44 years of age. This difference, al though statistically significant, should be interpreted with caution (see "Definitions of Terms"). Ever married women 15-19 were less likely to be in the labor force than ever married women 20-44 (41 percent compared with 52 percent). The ever married teenagers were not, however, significantly more likely to be receiving Aid to Families With Dependent Children (AFDC) than those 20-44 (9 percent compared with 7 percent).

Ever married teenagers were much more likely to be using the oral contraceptive pill at the date of the interview than ever married 
women 20-44 (51 percent compared with 22 percent-figure 1). Because use of the pill requires a doctor's prescription and medical followup, the high percent of teenage wives

\section{Figure 1. PERCENT OF WOMEN 15-44 YEARS OF AGE USING THE ORAL CONTRACEPTIVE PILL, BY AGE AND MARITAL STATUS: UNITED STATES, 1976}

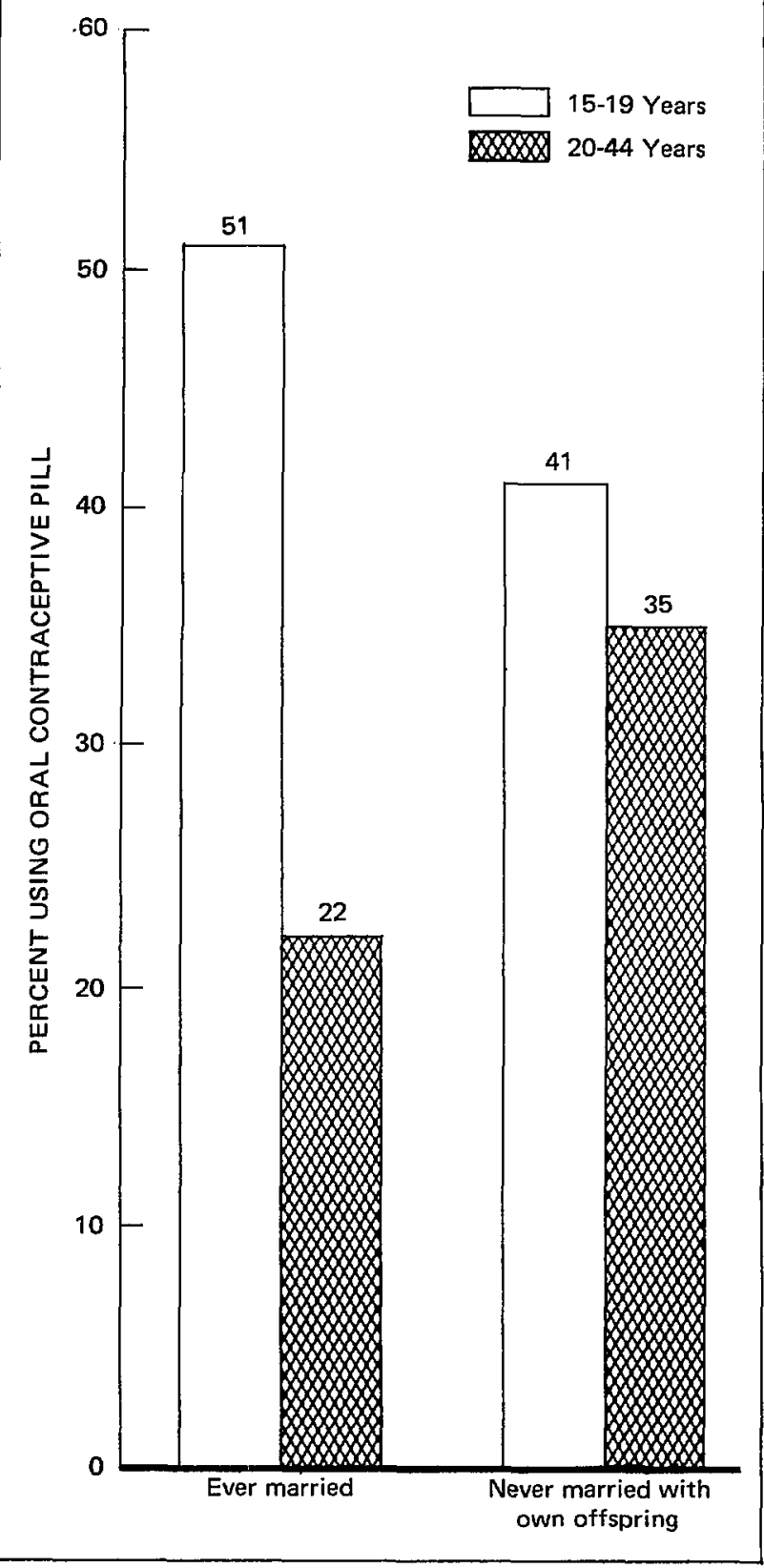

using the pill may be related to a finding in an earlier report that teenage wives were more likely than other wives to have had a recent family planning visit. ${ }^{7}$ In that report, the place where the most recent family planning visit occurred was classified as either "with own physician" or at an "organized medical service" (clinic or other place). The teenage wives were more likely than other wives to have had their most recent family planning visit at an organized medical service. Table 2 indicates that there was no significant difference between teenage and other ever married women in the percents trying to become pregnant or using the intrauterine device (IUD). Teenage wives were less likely than the ever married women $20-44$ to be using contraceptive methods other than the pill and IUD (12 percent compared with 19 percent).

Statistics in table 2 show that a larger proportion of ever married black women had their first child at a relatively young age than white ever married women did. About 28 percent of black ever married women $15-44$ had had their first birth before the age of 18 compared with about 9 percent of ever married white women. Similarly, overall and in both age groups, the percent of women with no birth by the date of interview was lower for black women than for white women.

The percent of ever married women who had a premarital birth was higher for black women among both teenagers and women 20-44 years of age. About 43 percent of black teenage wives and 5 percent of white teenage wives had a premarital birth. A recent study of teenage pregnancy may help to explain the larger percent of black ever married women than white ever married women who had a premarital birth (table 2). That study found that black single teenage women were more likely than white single teenage women to become premaritally pregnant, and much less likely than white single teenagers to marry before the outcome of a premarital pregnancy (see tables 1-3 of reference 3).

Selected characteristics of the husbands of teenage and other ever married women are shown in table 3. About 41 percent of the husbands of teenage wives were also teenagers at the wife's first marriage. Another 50 percent were 20-24 years of age; only 9 percent were 25 years of age or older. The data on the occupation of the 
wife's current or last husband show that 85 percent of the husbands of teenage wives were in "blue collar" occupations-craft, operatives, labor, transportation, farm labor, service, and kindred. This compares with 52 percent of the husbands of wives 20-44 years of age. Only 47 percent of teenage wives (table 2), but 66 percent of their husbands (table 3), had finished high school by the date of interview. This large difference may be explained in part by the older age of their husbands, but it may also reflect the wives' lower levels of educational attainment, or longer delays in completing high school. About 56 percent of teenage wives were living with both parents at the age of 14, compared with 70 percent of their husbands. Thus teenage wives were less likely than their husbands to have finished high school by the date of the interview and less likely to have come from two-parent households.

\section{CHARACTERISTICS OF SINGLE (NEVER MARRIED) MOTHERS}

From 1960 through 1976, the number of out-of-wedlock births in the United States increased from about 224,000 to 468,000 , a 109 percent increase (see table 5 of reference 1 ). One important reason for this increase was the rising number of young women during this period. Another was a widespread postponement of marriage. A third factor was an increase in the rate of out-of-wedlock births. The out-of-wedlock birth rate (out-of-wedlock births per 1,000 unmarried women 15-44 years of age) rose from 21.6 to 24.7 from 1960 through 1976, a 14percent increase. ${ }^{1}$ For unmarried women 15-19 years of age, however, this rate increased 57 percent, from 15.3 in 1960 to 24.0 in $1976 .{ }^{8}$ The rates for 1977 and 1978 were about the same as in 1976.

If a woman has had an out-of-wedlock birth, has kept the baby, and has never married, she is classified in this report as single with her own offspring living in the household. Table 4 shows selected characteristics of the estimated 332,000 single (never married) mothers 15-19 years of age and the 739,000 single mothers $20-44$ years of age who had offspring living with them in 1976. The single mothers were younger than the ever married women. About 65 percent of the single mothers were under 25 years of age compared with only 21 percent of ever married women.

Table 4 shows that 67 percent of the 332,000 single teenage mothers and 70 percent of the 739,000 single mothers $20-44$ years of age were black women. So black women accounted for a larger percent of single mothers than of the general population. This difference appears to reflect different outcomes of out-of-wedlock pregnancies among white and black teenagers as much as any difference in the chances of becoming pregnant in the first place. One recent study of teenage pregnancy revealed that black single teenage women were more likely than white single teenage women to become single mothers through a combination of five factors: a higher percent of black teenage women had had intercourse; a higher percent of black sexually active women had had a premarital first pregnancy; a lower percent of black premaritally pregnant women had married before the baby was born; a lower percent of black women had married soon after a premarital birth; and a larger percent of black than white teenage mothers had kept their babies. ${ }^{3}$

As mentioned previously, the living arrangements of the respondent at age 14 may be viewed as an indicator of the stability of her family life during her youth. About 42 percent of single mothers were living with only one or neither parent at age 14, compared with 23 percent of ever married women. Only about 1 in 5 (19 percent) single teenage mothers had finished high school by the date of interview, although 3 in 5 (61 percent) were 18 or 19 years of age at that date. This suggests that for many of these young women, motherhood interrupted their education. ${ }^{6}$

Table 4 also indicates that about 79 percent of single teenage mothers in 1976 had their first birth before the age of 18, compared with 29 percent of single mothers 20-44 years of age, 26 percent of teenage wives, and 11 percent of ever married women aged 20-44 years. The high proportion of very early first births for single teenage mothers probably reflects two facts: first, teenage mothers cannot by definition include any women whose first births occurred after age 19 , so the proportion with a birth before 17 is higher. Secondly, on reaching the age of 18 and the completion of high school, 
Table 4. Number of never merried women 15-44 years of age who have their own offspring living with them and percent distribution by selected characteristics, according to age: United States, 1976

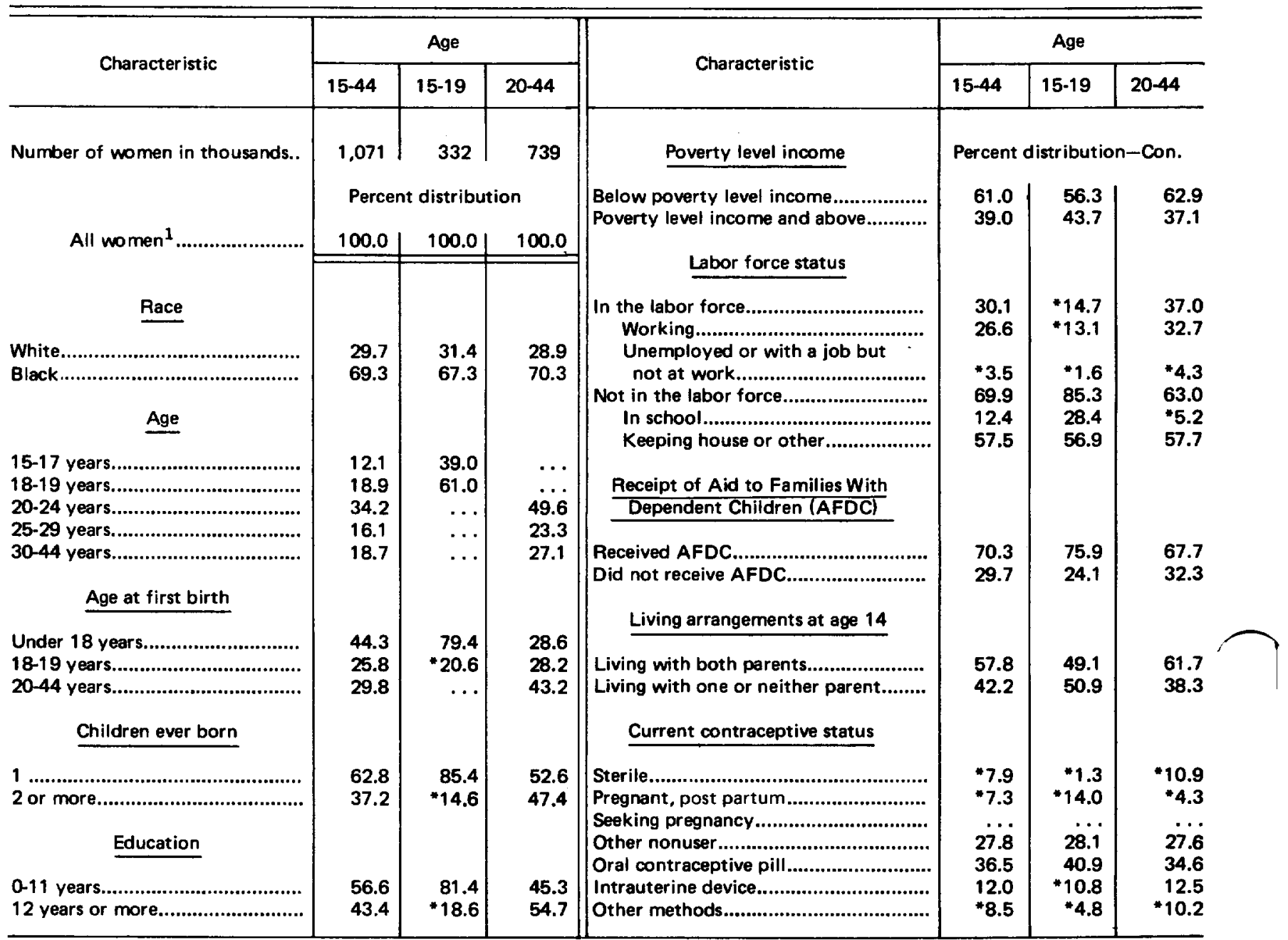

1 Includes white, black, and other races.

NOTE: Statistics in tables 2, 3, and 4 are based on a sample of the household population of the conterminous United States. See Technical Notes for estimates of sampling variability and definitions of selected terms.

women marry at a sharply increased rate $;^{9}$ thus many single teenage mothers may eventually marry, perhaps after they complete their education. They would therefore not be classified as single mothers at some later time, but rather as ever married women with a premarital birth.

Single mothers (table 4) were much more likely than ever married women (table 2) to be receiving AFDC (70 percent compared with 7 percent) and to have incomes below the poverty level (61 percent compared with 9 percent).
Overall and in both age groups, single mothers were less likely than ever married women to be in the labor force. In addition, the teenage single mothers were less likely than single mothers 20 44 to be in the labor force.

About 41 percent of teenage single mothers and 35 percent of those $20-44$ years of age were using the oral contraceptive pill at the date of interview (figure 1). This difference was not statistically significant. 


\section{REFERENCES}

${ }^{1}$ National Center for Health Statistics: Facts of Life and Death. DHEW Pub. No. (PHS) 79-1222. Public Health Service. Hyattsville, Md. Nov. 1978, table 4.

${ }^{2}$ National Center for Health Statistics: Teenage childbearing: United States, $1966-75$, by S. J. Ventura. Monthly Vital Statistics Report, Vol. 26, No. 5, Supp. DHEW Pub. No. (HRA) 77-1120. Health Resources Administration. Hyattsville, Md. Sept. 8, 1977, tables 1 and 2.

${ }^{3}$ Zelnik, M., and Kantner, J. F.: First pregnancies to women aged 15-19: 1976 and 1971. Fam. Plann. Perspect. 10(1): table 6, Jan.-Feb. 1978.

${ }^{4}$ Millman, S. R., and Hendershot, G. E.: Early fertility and lifetime fertility: evidence from the National Survey of Family Growth, Cycle II. Fam. Plann. Perspect. 12. May-June 1980.

${ }^{5}$ U.S. Bureau of the Census: Marital status and living arrangements: March 1976, Current Population Reports, Series P-20, No. 306, table 4. Washington. U.S. Government Printing Office, Jan. 1977.

${ }^{6}$ Moore, K. A., and Waite, L. J.: Early childbearing and educational attainment. Fam. Plann. Perspect. 9(5): 220-225, Sept.-Oct. 1977.
${ }^{7}$ National Center for Health Statistics: Use of family planning services by currently married women 15 44 years of age: United States, 1973 and 1976 , by G. E. Hendershot. Advance Data From Vital and Health Statistics, No. 45. DHEW Pub. No. (PHS) 79-1250. Public Health Service. Hyattsville, Md. Feb. 7, 1979.

${ }^{8}$ National Center for Health Statistics: Advance report, final natality statistics, 1976. Monthly Vital Statistics Report, Vol. 26, No. 12, Supp. DHEW Pub. No. (PHS) 78-1120. Public Health Service. Hyattsville, Md. Mar. 29, 1978, table 12; and National Center for Health Statistics: Vital Statistics of the United States, 1960 , Vol. I, Natality. Public Health Service. Washington. U.S. Government Printing Office, 1962, table I-X.

${ }^{9}$ National Center for Health Statistics: Advance report, final marriage statistics, 1976. Monthly Vital Statistics Report, Vol. 27, No. 6, Supp. DHEW Pub. No. (PHS) 78-1120. Public Health Service. Hyat tsville, Md. Sept. 13, 1978, table 3.

\section{SYMBOLS}

Data not available

Category not applicable-

Quantity zero-

Quantity more than 0 but less than 0.05 -----

Figure does not meet standards of reliability or precision 


\section{TECHNICAL NOTES}

\section{RELIABILITY OF ESTIMATES}

Because the National Survey of Family Growth (NSFG) is a sample of the household population of the conterminous United States rather than a complete count, the estimates in tables 2-4 are subject to sampling variability. To calculate the standard error of an aggregate number or percent, the appropriate estimates of $A$ and $B$ from table $\mathrm{I}$ are used in the equations

$$
\begin{aligned}
& S E_{\left(\mathrm{N}^{\prime}\right)}=\left(A+B / N^{\prime}\right)^{1 / 2} \times N^{\prime}, \text { and } \\
& S E_{\left(\mathrm{P}^{\prime}\right)}=\left[B \times P^{\prime} \times\left(100-P^{\prime}\right) / X^{\prime}\right]^{1 / 2},
\end{aligned}
$$

where $N^{\prime}$ is the number of women, $P^{\prime}$ is the percent, and $X^{\prime}$ is the number of women in the denominator of the percent. Statements in the text of this report were tested using a 2-tailed $\mathrm{t}$-test with 40 degrees of freedom. The relative standard error is the ratio of the standard error to the statistic being estimated. In this report, numbers and percents that have a relative standard error that is greater than 25 percent of the estimate itself are considered unreliable. They are marked with an asterisk to caution the user but may be combined to make other types of

Table 1. Estimates of $A$ and $B$ for relative standard error curves, by marital status and race: National Survey of Family

\begin{tabular}{|c|c|c|}
\hline $\begin{array}{l}\text { Marital status } \\
\text { and race }\end{array}$ & $A$ & $B$ \\
\hline \multicolumn{3}{|l|}{ Ever married } \\
\hline All races............. & 0.0001700390 & $6,486.5185$ \\
\hline 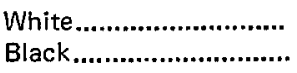 & $\begin{array}{r}0.0000422037 \\
-0.0004520643\end{array}$ & $\begin{array}{l}7,111.5185 \\
2,848.2362\end{array}$ \\
\hline$\frac{\frac{\text { Never married with }}{\text { own offspring and }}}{\text { ever married }}$ & & \\
\hline All races.............. & -0.0001926913 & $6,494.6569$ \\
\hline 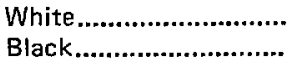 & $\begin{array}{l}-0.0002362857 \\
-0.0004813358\end{array}$ & $\begin{array}{l}6,892.2852 \\
2,698.6043\end{array}$ \\
\hline
\end{tabular}
Growth, Cycle II comparisons of greater precision. Details of the procedure used to estimate standard errors can befound in "National Survey of Family Growth, Cycle I: Sample Design, Estimation Procedures, and Variance Estimation," Vital and Health Statistics, Series 2, No. 76, January 1978. A similar report is in preparation for Cycle II.

In Cycle II of the NSFG, missing data items were not imputed, and percent distributions are based on cases with known data.

The NSFG estimates of numbers of ever married women 15-19 years of age, ever married women 15-19 years of age who had ever had a live birth, and never married (single) women 15-19 years of age living with their own offspring are in close agreement with estimates from other sources. In "Fertility of American Women: June 1976'' (Current Population Reports, Series P-20, No. 308, June 1977, table $43)$, the U.S. Bureau of the Census estimated a total of 1,125,000 ever married women 15-19 years of age, and of these, 505,000 were estimated to have had at least one child. Researchers at The Johns Hopkins University have provided an estimate of 311,000 never married (single) women 15-19 years of age living with their own offspring. This unpublished estimate is based on a 1976 sample survey of women 15-19 years of age in the noninstitutional population of the conterminous United States. None of these estimated numbers is significantly different from the NSFG estimate.

\section{DEFINITIONS OF TERMS}

\section{Demographic Terms}

Age.-In this report, "teenager" refers to a woman 15-19 years of age at the date of interview.

Marital status.-Persons are classified by marital status as married, widowed, divorced, separated, or never married. Married, widowed, divorced, and separated women are referred to as "ever married." For convenience, ever married women 15-19 years of age are also referred to as "teenage wives" since all but 7 percent of sampled ever married teenage women (19 cases) 
were currently married at the survey date. Never married women with offspring living in the household were included in the sample and classified separately in table 4.

Poverty level.-The poverty index ratio was calculated by dividing the total family income by the weighted average threshold income of nonfarm families with the head under 65 years of age based on the poverty levels shown in U.S. Bureau of the Census, Current Population Reports, Series P-60, No. 106, "Money Income in 1975 of Families and Persons in the United States," table A-3. Poverty level was not ascertained for 35 percent of sampled teenage mothers or for 18 percent of sampled teenage wives. Because missing data on income may be nonrandomly distributed with respect to other variables, small differences by poverty level income should be interpreted with great caution. "Below poverty level income" refers to a total family income that is less than the poverty threshold, while "poverty level income and above" refers to a total family income that equals or exceeds that threshold.

Receipt of Aid to Families With Dependent Children.-Respondents were asked, "Did you or any members of your family living here receive income in the past 12 months from ... welfare payments for aid to your dependent children?" Respondents who replied "yes" were classified as having received AFDC.

Labor force status. - Respondents were asked "Last week were you working full-time, parttime, going to school, keeping house, or what?" "In the labor force" includes those working fullor part-time; those with a job but not at work because of temporary illness, vacation, strike, or maternity leave; and those unemployed, laid off, or looking for work. "Not in labor force" includes those in school, those keeping house, and those engaged in other activities not in the labor force. This classification gives priority to working over other activities. For example, women who were both working and attending school, or working and keeping house, were classified as working.

\section{Current Contraceptive Status}

Sterile.-A woman (or couple) was classified as sterile if she reported that it was impossible for her to have a baby. Most of the women (or couples) classified as sterile have had sterilizing operations (see Advance Data No. 36).

Seeking pregnancy.-A currently married woman was classified as seeking pregnancy if she reported that she was not using a contraceptive method at the time of interview because she wanted to become pregnant. Never married mothers and widowed, divorced, and separated women were not asked if they were trying to become pregnant.

Post partum. -A woman (or couple) was classified as post partum if she reported that she was not currently using a contraceptive method, that she was not seeking pregnancy, and that her last pregnancy had terminated within 2 months before the date she was interviewed.

Other nonusers.-Women (or couples) who reported that they were currently using no contraceptive method and were not sterile, pregnant, post partum, or seeking pregnancy were classified here.

Method users.-A woman (or couple) who reported use of a contraceptive method other than a surgical sterilization at the date of interview was classified according to the specific method used. For a detailed classification of currently married women by specific contraceptive methods, see Advance Data No. 36.

\section{Related Data}

More extensive definitions of terms can be found in previous reports based on Cycle II of the NSFG-for example, see Advance Data Nos. $36,43,45,55$, and 56 . 
- Recent Issues of Advance Data From Vital and Health Statistics

No. 60. 1978 Summary: National Ambulatory Medical Care Survey (Issued: April 23, 1980)

No. 59. Trends in Breast Feeding: United States, 1973-75 (Issued: March 28, 1980)

No. 58. Remarriages of Women 15-44 Years of Age Whose First Marriage Ended in Divorce: United States, 1976 (Issued: February 14, 1980)
No. 57. Office Visits for Diabetes Mellitus, National Ambulatory Medical Care Survey: United States, 1977 (Issued: January 25, 1980)

No. 56. Wanted and Unwanted Births Reported by Mothers 15-44 Years of Age: United States, 1976 (Issued: January 24, 1980)

A complete list of Advance Data From Vital and Health Statistics is available from the Scientific and Technical Information Branch.

\section{NCHS}

U.S. DEPARTMENT OF HEALTH AND HUMAN SERVICES Public Health Service

Office of Health Research, Statistics, and Technology

National Center for Health Statistics

3700 East-IVest Highway

Hyattsville, Maryland 20782

PENALTY FOR PRIVATE USE, $\$ 300$

HHS Publication No.

(PHS) 80.1250
POSTAGE AND FEES PAID U.S. DEPARTMENT OF H.H.S. HHS 396

FIRST CLASS MAIL 